ISSN : 2550-0198

\title{
PELATIHAN DESAIN KEMASAN PRODUK UMKM DI KECAMATAN TAMBANG, KABUPATEN KAMPAR
}

\author{
Zayyinul Hayati Zen*, Satriardi, Dedi Dermawan, Denny Astrie Anggraini, \\ St. Nova Meirizha, Faradila Ananda Yul \\ Prodi Teknik Industri, Fakultas Teknik, \\ Universitas Muhammadiyah Riau. \\ * Email: zayyinulhayati@umri.ac.id
}

\begin{abstract}
Abstrak
Kemasan (packaging) merupakan salah satu ujung tombak penjualan suatu produk. Kemasan mempunyai peranan yang sangat penting karena akan selalu terkait dengan komoditi yang dikemas dan sekaligus merupakan nilai jual dan citra produk. Nilai jual ini meningkat ketika produk yang dihasilkan mendapat nilai tambah dari kemasan yang menarik. Sedangkan citra produk terkait dengan gambaran produk dalam benak konsumen akan semakin baik apabila produk itu dikemas secara baik, dengan kata lain produk dapat memberi kesan baik bagi konsumen. Pelatihan desain kemasan produk untuk pelaku UMKM di Kabupaten Kampar ini untuk memberikan wawasan desain dan bentuk kemasan baru yang membuat produk menjadi lebih bernilai dan aman. Metode yang diterapkan dalam kegiatan ini adalah metode presentasi mengenai pengenalan bentuk dan desain packaging, Metode demonstrasi mengenai contoh kemasan produk yang baik disesuaikan dengan produk yang diproduksi oleh UMKM, dilanjutkan dengan diskusi untuk menganalisis beberapa kemasan produk pembanding. Metode evaluasi dengan mengamati hasil pelatihan yang didapat, yaitu peserta terlihat sangat antusias dan berdiskusi aktif untuk pengembangan kemasan produknya agar lebih bernilai jual. Pendampingan akan terus dilakukan setelah kegiatan pelatihan ini. Tim pelaksana dari Program Studi Teknik Industri akan selalu siap membimbing dan mengarahkan pelaku usaha dalam pengembangan usahanya.
\end{abstract}

Kata kunci: Pelatihan desain kemasan, UMKM

\section{PENDAHULUAN}

Sektor Usaha Mikro, Kecil dan Menengah (UMKM) memegang peranan penting dalam pembangunan ekonomi Indonesia. Hal itu dikarenakan UMKM berkontribusi cukup besar terhadap komposisi Produk Domestik Bruto (PDB). Angkanya terlihat menggeliat lima tahun terakhir, meningkat dari 57,84 persen menjadi 60,34 persen. Tidak hanya itu, sektor UMKM juga telah membantu penyerapan tenaga kerja di dalam negeri. Serapan tenaga kerja pada sektor UMKM tumbuh dari
96,99 persen menjadi 97,22 persen dalam periode lima tahun terakhir.

Kontribusi UMKM
mengangkat perekonomian rakyat.
Oleh karena itu,
pemberdayaan terhadap UMKM
sangat dibutuhkan. Salah satu upaya
yang dapat dilakukan untuk
pemberdayaan UMKM adalah
pelatihan desain kemasan produk.
Banyak produk sejenis di pasar yang
diproduksi perusahaan luar negeri
yang menguasai pasar lokal dengan
mengalahkan produk UMKM
Indonesia. Penyebabnya adalah
kemasan produk lokal yang kurang


menarik minat lokal dan dianggap tidak higienis. Padahal apapun produknya, jika dikemas baik maka akan menambah nilai tambah dari produk tersebut. Kemasan produk kita masih sangat sederhana untuk bisa bersaing dengan produk luar.

Salah satu faktor penting pada sebuah produk adalah kemasan. Kemasan seringkali disebut sebagai "the silent sales-man/girl" karena mewakili ketidakhadiran pelayan dalam menunjukkan kualitas produk. Untuk itu kemasan harus mampu menyampaikan pesan lewat komunikasi informatif, seperti halnya komunikasi antara penjual dengan pembeli. Para pakar pemasaran menyebut desain kemasan sebagai pesona produk (the product charm), sebab kemasan memang berada di tingkat akhir suatu proses alur produksi yang tidak saja untuk memikat mata (eye-cathing) tetapi juga untuk memikat pemakaian (usage attractiveness).

Dalam era globalisasi saat ini, kemasan mempunyai peranan yang sangat penting karena akan selalu terkait dengan komoditi yang dikemas dan sekaligus merupakan nilai jual dan citra produk. Nilai jual ini meningkat ketika produk yang dihasilkan mendapat nilai tambah dari kemasan yang menarik. Sedangkan citra produk terkait dengan gambaran produk dalam benak konsumen akan semakin baik apabila produk itu dikemas secara baik, dengan kata lain produk dapat memberi kesan baik bagi konsumen.

Berdasarkan pemaparan diatas, memunculkan gagasan penting untuk melihat dan menganalisa kemasan produk UMKM yang ada di Kecamatan Tambang, Kabupaten Kampar saat ini. Dinas Perindustrian Perdagangan Koperasi dan UMKM juga mengharapkan dilaksanakannya sebuah pelatihan terhadap UMKM mengenai kemasan. Ini diharapkan sebagai upaya peningkatan daya saing produk UMKM dengan produk industry lainnya, baik produk dalam negeri sendiri bahkan luar negeri.

\section{METODE PENGABDIAN}

Metode yang digunakan dalam pelaksanaan pengabdian adalah metode presentasi mengenai pengenalan bentuk dan desain packaging, Metode demonstrasi mengenai contoh kemasan produk yang baik disesuaikan dengan produk yang diproduksi oleh UMKM, dilanjutkan dengan diskusi untuk menganalisis beberapa kemasan produk pembanding.

\section{HASIL DAN PEMBAHASAN}

Kegiatan pengabdian ini terlaksana karena adanya tawaran Pusat Layanan Usaha Terpadu (PLUT) Kabupaten Kampar dibawah Dinas Perdagangan Koperasi dan UMK dengan Program Studi Teknik Industri Fakultas Teknik UMRI untuk bekerja sama dalam membantu meningkatkan kualitas produk UMKM Kabupaten Kampar. Kegiatan pengabdian kepada masyarakat Kabupaten Kampar dengan pokok materi pelatihan desain kemasan UMKM, dalam hal ini peserta diberikan bekal mulai dari pengenalan konsep pentingnya kemasan produk, kemasan standar 
ISSN : 2550-0198

untuk UMKM, kreatifitas desain kemasan untuk UMKM, labelling dan pengunaan barcode (code Batang),PIRT, logo halal (komponen penting pada kemasan), branding/merk pada kemasan, dan trend kemasan saat ini. Pelaksanaan pengabdian ini dilakukan dalam bentuk penyuluhan, Tanya jawab, diskusi hingga penyelesaian kasus. Diharapkan dengan adanya pengabdian masyarakat ini UMKM mendapatkan wawasan dan pengetahuan tentang konsep pentingnya kemasan produk. UMKM mengetahui fungsi, kegunaan dan jenis kemasan yang dapat diterapkan pada produknya. Mampu merancang strategi kreatif desain kemasan dan perencanaan desain kemasan, serta mengetahui trend kemasan yang berlaku sekarang. Serta UMKM dapat merancang kemasan yang baik dan inovatif untuk produknya sehingga memberi nilai jual terhadap produk UMKM.

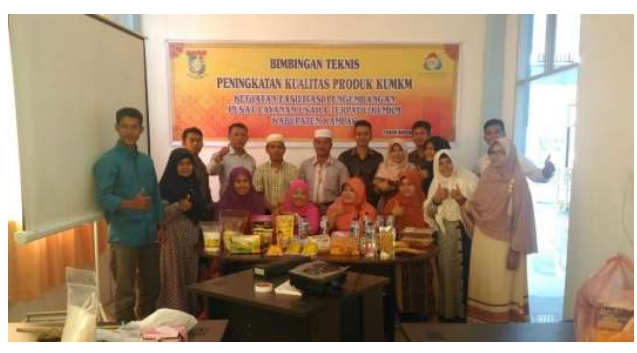

Gambar 1. Pelatihan Desain Kemasan Kab. Kampar,2017

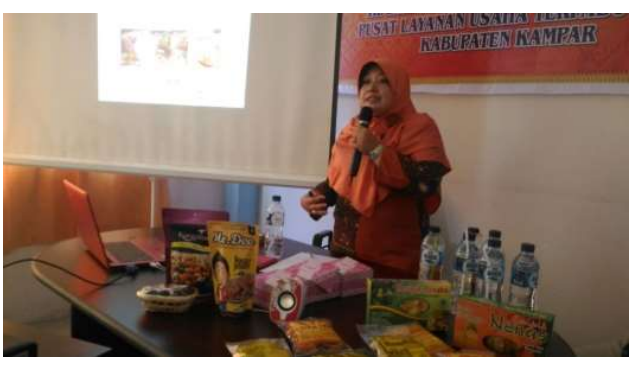

Gambar 2. Pemamaparan materi 1

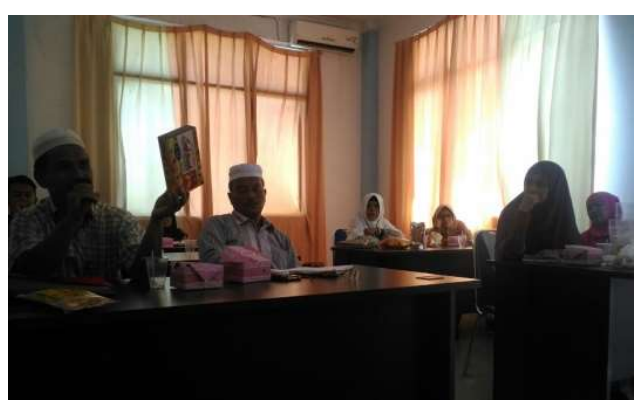

Gambar 3. Dialog dengan Peserta

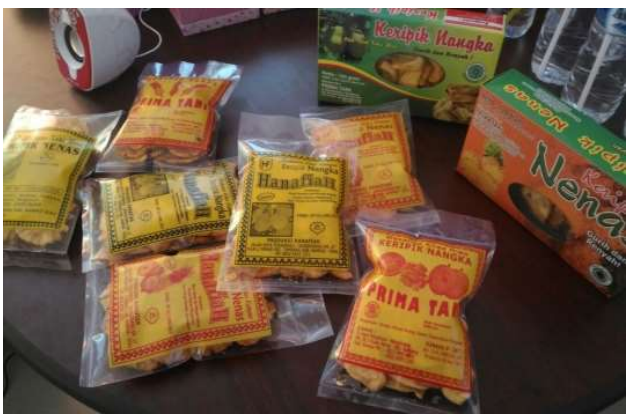

Gambar 4. Hasil Kemasan

\section{SIMPULAN}

Pelatihan ini memberikan beberapa materi yang terkait dengan upaya meningkatkan nilai dan kualitas produk UMKM di Kabupaten Kampar melalui penerapan kemasan yang sesuai. Materi yang disajikan dapat diterima, dicerna, dan dipahami peserta dengan baik. Kegiatan berlangsung lancar, tepat waktu dan sesuai dengan yang diharapkan dan para peserta dapat berkomunikasi dengan para pembicara dan peserta lain dengan baik.

\section{UCAPAN TERIMAKASIH}

Ucapan terimakasih kami sampaikan kepada Lembaga Penelitian dan Pengabdian Masyarakat Universitas Muhammadiyah Riau sebagai pemberi dana dalam kegiatan pengabdian kepada masyarakat yang telah dilaksanakan pada bulan 
ISSN : 2550-0198

Agustus 2017 di Kecamatan Tambang, Kabupaten Kampar. Serta ucapan terimakasih kami ucapkan kepada Tim Pusat Layanan Usaha Terpadu (PLUT) Kabupaten Kampar dibawah Dinas Perdagangan Koperasi dan UMK yang sudah menjembatani pihak pelaksana dengan peserta dalam pelaksanaan Pengabdian Kepada Masyarakat.

\section{DAFTAR PUSTAKA}

[1] Aaron L. Bradly, Kenneth S. Marsh, The Wiley Encyclopedia of Packaging Technology, 2nd edition, A Wiley Interscience Publication, John Wiley \& Sons Inc., Canada, 1997

[2] Anonim, Indonesian Packaging Companies, Directory and Profiles 2002, PT. Carpricorn Indonesia Consult Inc., A Member of The CIC Consulting Group,Jakarta, 2002

[3] Coles R. Mc. Dowell D. Kirwan MJ. 2003. Packaging Tecnology. Boca Raton. CRC Press

[4] Klimchuk, Marianne Rosner \& Sandra A.Krasovec. (2007). Desain Kemasan Perencanaan Merek Produk yang Berhasil Mulai dari Konsep sampai Penjualan. Trans. Bob Sabran. Jakarta : Penerbit Erlangga.

[5] Swann, Allan.1997. The New Graphic Design School.
London : New Burlington Books.

[6] Wirya, Iwan. 1999. Kemasan Yang Menjual. Menang Bersaing Melalui Kemasan. Cetakan Pertama. Gramedia Pustaka Utama. Jakarta 